\title{
$35(3) \cdot 2021$
}

ISSN 2080-1653

DOI 10.24917/20801653.353.20

\author{
SŁAWOMIR DOROCKI \\ Pedagogical University of Kraków, Poland
}

\section{Tourism on a motorcycle: an attempt to describe motorcycle tourism in Poland based on the results of an internet survey conducted before the COVID-19 pandemic}

\begin{abstract}
Motorcycle tourism is a segment that has seen a substantial increase in interest in Poland and globally. Factors that encourage users of Powered Two-Wheelers (PTW) to set off on a journey, although largely convergent with other types of tourism, differ in terms of the method of travel and destination. The article attempts to describe domestic motorcycle tourism based on an internet survey. The text attempts to define the profile of a person engaged in such tourism and the destination of motorcycle tours in Poland and the world. An attempt is also made to clarify the concept of "motorcycle tourism".
\end{abstract}

Keywords: motorcycle, motorcycle tourism, PTW, two-wheelers

Received: 11 July 2021

Accepted: 1 August 2021

Suggested citation:

Dorocki, S. (2021). Tourism on a motorcycle. An attempt to describe motorcycle tourism in Poland based on the results of an internet survey conducted before the COVID-19 pandemic. Prace Komisji Geografii Przemysłu Polskiego Towarzystwa Geograficznego [Studies of the Industrial Geography Commission of the Polish Geographical Society], 35(3), 320-332. doi: https://doi.org/10.24917/20801653.353.20

\section{INTRODUCTION}

As a result of the socio-economic development of Poland after accession to the European Union, there was a marked increase in wealth in society (Panek, 2015), and with the improvement in wealth has been an increase in demand for leisure services (Zalega, 2013). A manifestation of this is the growing demand for luxury goods, including Powered Two-Wheelers (PTW), mainly motorcycles. Nowadays, these vehicles have less and less of a communication function and are used primarily for entertainment and recreation (Dorocki, 2019a). Since 2004, the number of PTW vehicles has more than doubled (Figure 1), and the most significant increase has been recorded for mopeds (vehicles with an engine capacity of up to $50 \mathrm{cc}$ ), the share of which in the total for PTW 
Figure 1. Number of PTW vehicles in Poland in 2004-2016 by percentage

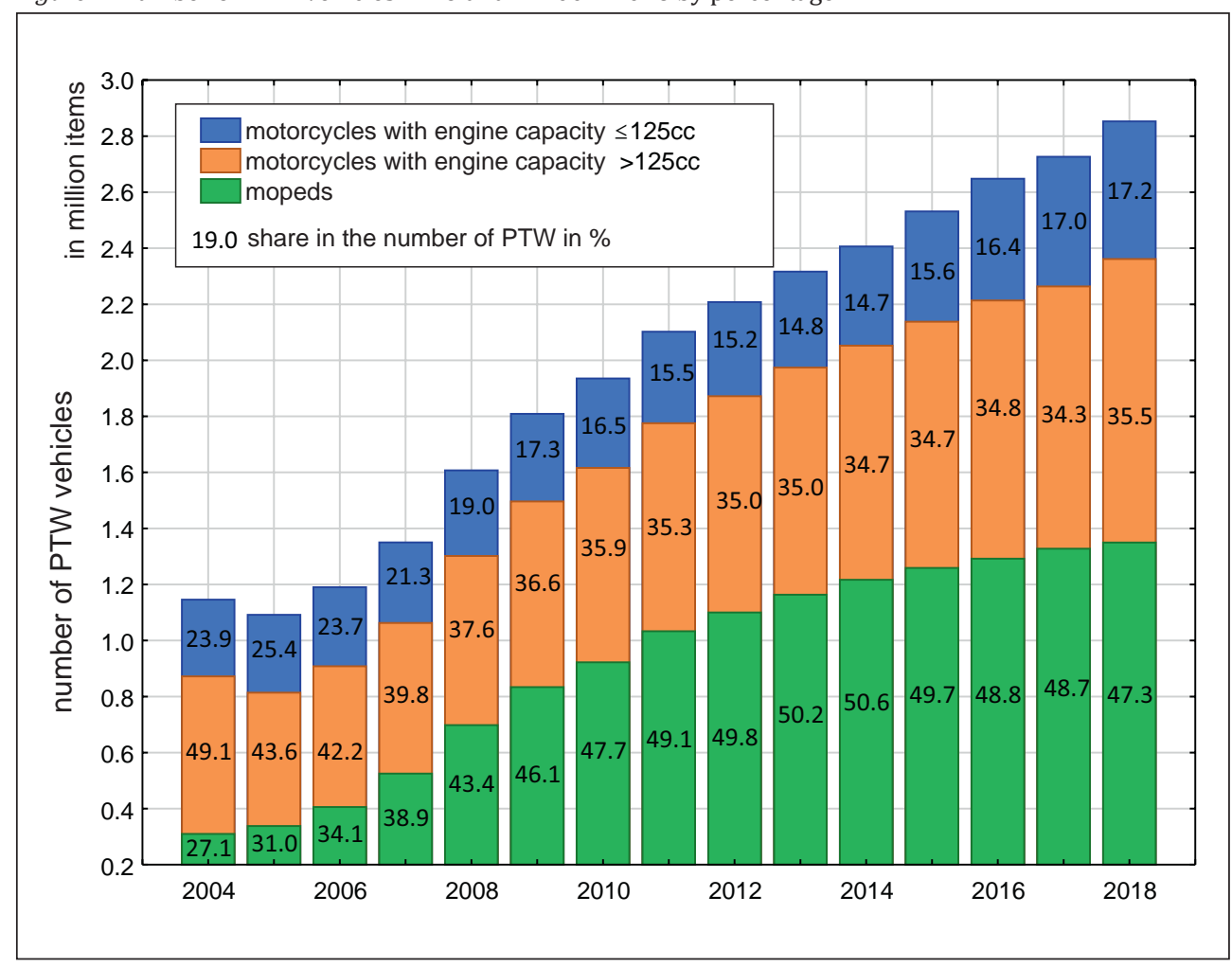

Source: author based on the Główny Urząd Statystyczny [Central Statistical Office]

vehicles has increased from approximately $27 \%$ at the beginning of the analysed period to approximately $47 \%$. It is mainly due to the availability of cheap vehicles imported or produced in Poland (Dorocki, 2019b) and growing transport difficulties in cities (Dorocki, Wantuch-Matla, 2021).

The increase in the number of PTW vehicles has influenced the popularity of motorcycle tourism. This mainly applies to owners of motorcycles with an engine capacity greater than $125 \mathrm{cc}$. In the case of mopeds and "light motorcycles" (engine capacity up to $125 \mathrm{cc}$ ), functions related to daily communication and short-distance journeys prevail.

The article aims to attempt to describe motorcycle tourism in Poland. The following research questions were posed: what are the destinations for motorcyclists' journeys, how often and how long do motorcycle trips last, and what factors determine the choice of route and its attractiveness.

Research on motorcycle tourism began in the 1990s, and motivations for motorcyclists' trips were researched by, among others, Arnouldi and Price (1993), Schouten and McAlexandar (1995), and Austin and Gagne (2008). The theory of motorcycle tourism was undertaken by Urry (2002), Swanson (2007), Ritchie and Hudson (2009), Price-Davies (2011) and Walker (2011). Issues of destinations for motorcycle tourism were dealt with by Jansen-Verbeke (2008), Weidenfeld, Butler, Williams (2010), Sykes 
and Kelly (2014). Corey (1997) and Sykes and Kelly (2014) wrote about the demand for motorcycle tourism.

The subject of motorcycle tourism in Poland and attempts to describe it based on surveys have already been undertaken several times. Worth mentioning is the monograph by Biedron from 2011 entitled Motorcycle tourism in Poland: characteristics of the phenomenon and its consumers [in Polish]. Among other published items, it is worth noting the article by Zawadka (2015), Motorcycle journeys as a niche form of qualified tourism and the preferences and behaviours of their participants [in Polish], and a multi-authored article entitled The geography of selected sightseeing experiences of motorcyclists engaged in scooter tourism associated with the Burgmania club [in Polish] (Wilk et al. 2017). Also noteworthy is the historical view of the development of motorcycle tourism in Galicia (Kurek, 2008) and during the Polish People's Republic (Sosnowski, 2015). The following study, therefore, complements previous research and, in the future, will allow for an analysis of the changes that have been occurring in motorcycle tourism in Poland.

\section{RESEARCH METHODS AND TECHNIQUES}

Motorcycle tourism characteristics in Poland are based on data obtained from an internet survey (CAWI) conducted between April and June 2020. The research tool in the CAWI method is an electronic research survey, and it was planned to supplement this with a direct questionnaire (PAPI). However, the COVID-19 pandemic forced its limitation to remote research. The online questionnaire consisted of four sections: the first included the respondent's data (age, gender, place of residence, license to drive L-class vehicles); the second contained questions about the vehicles used followed by the general use of PTW vehicles; and finally questions about motorcycle tourism, including the experiences of the respondents. The questionnaire consisted of open and closed questions.

The survey was made available on the following websites: Interesting places and motorcycle routes (www.facebook.com/Moto-Opinieinfo-165103736936391), MotoPodhale.info (www.facebook.com/motopodhale.info) and Vespa Club Małopolska (www.facebook.com/MSMPV).

One hundred seventy-four people replied, so it should be treated as just a research sample. Due to the lack of available information on the size and diversity of the general population of those engaged in this type of tourism in Poland, it is difficult to determine the degree of representativeness of this research sample. Therefore, the information obtained from the survey does not allow generalisations to be made on conclusions for the entire population of motorcycle tourists in Poland. In the analysis of the survey results, tables and charts have been used.

\section{MOTORCYCLE TOURISM}

Motor tourism is defined as "the entirety of relations and phenomena related to the travel and stay of tourists who use motor vehicles as the means of transport" (Biedron, 2011: 15). It is classified as 'qualified' tourism, which requires specialist equipment and the appropriate qualifications for the driver. A particular type of motor tourism is motorcycle tourism, also known as motorcycling, in which two- and three-wheeled 
motorised vehicles are used. The most essential element of motorcycle tourism is the journey itself (the road) and the pleasure derived from riding. The travel destination itself and the feelings associated with it may be less important than the journey (Walker, 2011). This type of tourism is similar to cycling, canoeing or hiking, where the very fact of travelling is the leading 'destination'. Thus, motorcycle tourism is distinct from cars, where the destination is essential (Pinch, Reimer, 2012) and more similar to off-road sports (Carson, Taylor, 2008). For motorcycling, the importance of the sightseeing nature of the journey should be emphasised (Botterill et al., 2000).

An increasing number of people seek free and independent travel experience (Shih, 2006), and this need is satisfied by motorcycle tourism. The independence means that it impacts regional tourism patterns and is therefore particularly important for peripheral areas (Cater, 2017a). In addition, coastal and mountain areas have winding roads preferred by motorcyclists while the period of the COVID-19 pandemic has increased the need for individual tourism with limited contact with other tourists.

Although motorcycle trips, even over long distances, are not a new way of using PTW vehicles, they have become more common (Hall, 2013). In Western Europe, more than half of motorcyclists travel abroad (Cater, 2017b), while motorcycle trips are popular to the so-called warmer countries (in Europe, e.g. Spain, Italy, Croatia) along with extreme expeditions to Siberia, Mongolia or the North Cape.

Motorcycle tourism is the fastest-growing segment of tourism in the USA (Sykes, Kelly, 2014). The organisation of motorcycle events in the USA gathers over 600000 people, and recreation is crucial for using PTW vehicles (Chorlton, Jamson, 2003).

Lamont (2009) noted that there is no clear definition of motorbike tourism, which is similar to cycling. First of all, there are no objective criteria such as the number of travel days or the distance travelled in kilometres. The biggest problem is to distinguish entertainment and sport from tourism. Therefore, based on the definition of cycling tourism (which seems largely similar to motorcycle tourism), an attempt has been made to define that for motorcycling.

Motorcycle tourism covers a journey made in a PTW vehicle away from the person's place of residence. This may include trips lasting several hours, one day or several days. Tours are non-competitive (if they are competitive, they should be included in sports). Riding should be the primary purpose of a trip, and it should be a form of recreation and relaxation. However, unlike recreation itself and entertainment, trips must include an element of sightseeing. It should be noted that nowadays, in the era of the development of electric vehicles (including electric bicycles), the boundaries between cycling and motorbike tourism may be blurred. The only difference may be in covering a given distance within a specific time.

Motorcycle tourism research can be conducted on two levels: the characteristics of motorcycling as use of PTW vehicles; and the spatial dimension of motorcycle tourism. This second aspect is essential in relation to local economic development through the multiplier effect. Tourism can stimulate the development of entire regions (Kosmaczewska, 2013). Several factors confirm the possibility of using motorcycle tourism to stimulate the development of tourist services: because of luggage restrictions, motorcyclists are consumers of goods and services, while travelling by motorcycle is an activity that requires more frequent stops, physically for rest and technically (tank capacity). However, the mobility of PTW vehicles is greater than that of other means of transport (low requirements for road infrastructure). In addition, motorcycle tourism 
is often peripheral (Hohl, Tisdell, 1995), affecting the development of rural areas (Austin, Gagne, 2008; Way, Roberts, Turner, 2010; Walker, 2011). Moreover, according to research, motorcyclists do not have the exact needs and desires as other tourists (Sykes, Kelly, 2014): about 53\% consider the route's sightseeing value as the leading 'destination', and 84\% discovering new places, including historical sites (Sykes, Kelly, 2016). Carson and Cartan (2011) suggest that tourist routes combine multiple destinations and may be marketed as a 'collective entity'.

\section{MotoRCYCLE TOURISM IN POLAND}

\section{Motorcycle tourism destinations}

As shown in the introduction, the use of PTW vehicles for recreational and entertainment purposes is growing in Poland. This mainly applies to motorcycle owners, although there is a large group of enthusiasts for PTW vehicles with a smaller engine capacity (e.g. Vespa scooters, old motorcycles or motocross bikes).

Among the respondents, the most prominent groups came from Kraków (43), Warsaw (12) and the 'Tri-City' - Gdańsk-Sopot-Gdynia (10). In general, Małopolskie Voivodeship had the most, with 94, but this was related to research conducted in the Kraków centre. The study was dominated by men (87\%) but with a similar mean age for both sexes of approximately 37 (Table 1). Most of the respondents had almost ten years of experience in using PTW vehicles, and most were users of touring motorcycles (42\%) or 'naked' motorcycles (18\%) as well as scooters and maxi-scooters (approx. 15\%). The average engine size was over $600 \mathrm{cc}$. More than half of the respondents owned more than one PTW vehicle. Therefore they are primarily riders with extensive experience, and as owners of PTW vehicles, they are capable of long and comfortable journeys.

Table 1. Respondents according to demographic characteristics and the technical data of the vehicles used

\begin{tabular}{|l|c|c|c|c|c|}
\hline gender & no & $\begin{array}{c}\text { average } \\
\text { age (yrs) }\end{array}$ & $\begin{array}{c}\text { average age of obtaining a PTW } \\
\text { driving licence (age) }\end{array}$ & $\begin{array}{c}\text { average engine } \\
\text { capacity }\left(\mathrm{cm}^{3}\right)\end{array}$ & $\begin{array}{c}\text { average number } \\
\text { of PTWs }\end{array}$ \\
\hline female & 22 & 36.86 & 29.28 & 501.36 & 1.36 \\
\hline male & 152 & 36.58 & 24.45 & 678.82 & 1.86 \\
\hline total & 174 & 36.62 & 25.03 & 656.64 & 1.80 \\
\hline
\end{tabular}

Source: author based on questionnaires

On average, the respondents travelled around $8000 \mathrm{~km}$ a year (median), and there was a correlation $(r=0.62)$ between engine capacity and kilometres travelled during a year.

Two hundred eighty-eight routes were analysed, of which 178 trips (61.8\%) took place partially or entirely outside Poland. These have taken place since 1991 for domestic trips and since 2002 for foreign ones, with most covering the years 2016-2019 (240 trips). On average, trips abroad lasted about two weeks (12.7 days), while domestic trips lasted 3.7 days. It should be noted that there were riders who made expeditions lasting half a year or almost a whole year among the respondents. One was a trip from Kraków to New York (approx. 300 days), others from Peru to Chile (about four months) and from Kalisz to Vladivostok (about four months). 
As the changes in the market for tourist services indicate, there is a growing demand for motorcycle trips organised by travel agencies to distant parts of the world (Zawadka, 2015). The organisers of such expeditions provide motorcycle equipment and maintenance in situ while offers also include other accompanying attractions such as sightseeing, diving and paragliding. From the questionnaires, there had been trips from Barcelona (Spain) to Girona (Spain), Kutaisi (Georgia) to Tbilisi (Georgia), Ulan Bator (Mongolia) to Gornoaltask (Russia).

In the case of foreign destinations, towns in southern Europe dominated: Romania (16) and Croatia (15) with Slovakia and Italy (12), Albania and Hungary (11), Greece (10) and Montenegro (7). In addition, three trips took place to the Balkans without specifying the exact destination. One of the main factors for the popularity of the Balkan and Apennine Peninsulas among Polish motorcyclists is the Polish custom of taking a long summer holiday. Countries such as Italy, Greece and Croatia that offer "sun and sea" are the most common foreign holiday trips (Łysoń, 2019: 114). The Balkans, particularly the Romanian Carpathians, offer attractive motorcycle routes and the Transfagarasan route and the Transalpina are the destinations of many motorcyclists as indicated by many respondents.

The costs of accommodation and travel can be another factor. The countries of Central and Eastern Europe are economically more attractive to Poles than the countries of Western Europe. It should be remembered that due to the maximum load capacity of motorcycles and much smaller capacity of fuel tanks than in the case of cars, motorcyclists, unlike car tourists, are forced to make purchases abroad.

The destinations of motorcyclists' journeys were usually attractive tourist regions: Lake Balaton in Hungary, the Tatra Mountains in Slovakia, the Alps in Italy, Dubrovnik in Croatia or Corsica in France. At the same time, some questionnaires indicated no specific destination, but only the journey itself, e.g. along the Adriatic coast or through the Carpathian Mountains or the Alps. The length of a journey depending on the distance from Poland: to Slovakia, lasting on average 1.6 days, Hungary 5.5 days, Romania 7.8 days, Croatia 8.9 days, Albania 12 days and Greece 13.9 days. These trips were usually organised by groups of people, on average 4-5.

Outside the Balkans and Italy, Polish motorcyclists often chose a westerly direction reaching the Alps and the Mediterranean islands of Corsica, Sardinia and Sicily. Turkey (Istanbul) and Ukraine are also popular regions. However, trips east of the Polish border were less popular, as was a northerly direction. An exception is the North Cape (Nordkapp), which is a challenge for motorcyclists and is treated, after mountain routes in the Alps and Carpathians, as a popular destination for long-distance motorcycling in Europe (Cater, 2017a), and at the same time being an important place in itself for mass tourism (Spring, 2017).

A dozen or so respondents indicated organised tourist trips aimed at motorcycle tourism, e.g. New Zealand, South America, Spain (including Majorca), Morocco, Georgia, Bulgaria and Croatia. Such distant places as Vladivostok, Murmansk (Russia) and New York (USA) were among those indicated. However, these were single expeditions. Motorcycle tourism takes place on rented or previously sent equipment, which shortens the travel time to the destination and reduces the inconvenience of travel for the elderly (McInnes, Williamson, Morrison, 2002). These trips are often organised by specialised travel agencies (Hermawati et al., 2019). 
The location of the tourists' place of residence largely determines the choice of the destination. For domestic trips, mountainous and coastal regions and Warmia and Mazury dominate while other destinations include large cities such as Kraków or Warsaw. Among these, both weekly, 2-3-day (weekend) and one-day trips are found.

When analysing the directions of the routes, it can be concluded that the inhabitants of southern Poland most often go to the seaside (weekly trips), while weekend trips are mainly to the Beskidy, the Tatras and the Bieszczady Mountains. Warmia and Mazury are the choices of the inhabitants of the capital and Wielkopolska. The inhabitants of Silesia choose the mountains (Beskidy and Bieszczady) as well as Warmia and Mazury. Generally, excursions to towns located within $100 \mathrm{~km}$ from the place of residence predominate among one-day trips. For example, motorcyclists from Kraków choose Lanckorona (35 km), Wadowice (50 km), Zakopane (100 km) or Nidzica (110 km) as destinations for one-day trips.

According to the number of trips made by the respondents, the Bieszczady Mountains (including the large and small loop Bieszczady routes and the Słonne Mountains) came first, followed by the Kłodzko Valley (a 'hundred bends' road), the Sudety and the Karkonosze Mountains. These are followed by Podhale and the Tatra Mountains (loop) and eastern Poland (Roztocze, Mazury and Podlasie).

\section{Characteristics of motorcycle tours}

The length of a trip depends mainly on the destination. Among domestic trips, those for one day or up to five days are predominant. On the other hand, more than a week is spent on trips abroad, most often lasting seven to ten days. Domestic trips longer than ten days are sporadic, but more than half of domestic tours last more than a day.

About $44 \%$ of respondents go on trips several times a year, and as many as $33 \%$ even several times a month. There are usually one or two longer trips (approximately 7 days) and several shorter ones (weekend or one-day trips). In half of the answers, the respondents stated that the length of their trips varies greatly. This confirms the thesis that motorcyclists make several long trips and more frequent one to two-day trips for shorter distances during the season. About $28 \%$ of the respondents indicated that they travelled up to $100 \mathrm{~km}$ from their place of residence. This mainly applies to residents of large cities where the motorcycle is mainly an entertainment alongside other leisure activities. On the other hand, in smaller towns and rural areas, long weekend trips (more than $200 \mathrm{~km}$ from their residence) prevail (15\% of respondents). People from cities also prefer long-distance trips (usually one in a season). Only 6\% indicated that they participate in trips in the immediate vicinity, mainly young people and only males; perhaps, for women, owning a motorcycle is more related to a specific use than for men. Based on an in-depth individual interview, it can be seen that there is a significant difference in approach to motorcycle use in terms of tourism by gender. Women show more tourist activity than men. Men emphasise sport (competition, testing their skills as a rider) and challenge (e.g. challenging routes, off-road) over tourism. Moreover, unlike women, they are more pragmatic in using motorbikes, e.g. travel time to work. Although men still dominate among users of PTW vehicles in Poland, a steady increase in interest in motorcycle tourism among women is noticeable.

Analysing responses to the frequency and distance of trips broken down by gender, trips made several times a year at widely differing distances dominate. For women, 
it is the exact figure for several times a month up to $100 \mathrm{~km}$ from home, and several times a year, at variable distances (Table 2). For women, a high proportion (almost 12\% of responses) indicated trips over $200 \mathrm{~km}$ from their residence several times a month.

Table 2. Percentage of responses related to the frequency of tourist trips (columns) and distances (rows) by gender

\begin{tabular}{|c|c|c|c|c|c|c|c|c|c|}
\hline \multirow[t]{2}{*}{ frequency distance } & \multicolumn{3}{|c|}{$\begin{array}{c}\text { once-twice a year } \\
(\%)\end{array}$} & \multicolumn{3}{|c|}{$\begin{array}{c}\text { several times a month } \\
(\%)\end{array}$} & \multicolumn{3}{|c|}{$\begin{array}{c}\text { several times a year } \\
(\%)\end{array}$} \\
\hline & $\mathrm{M}$ & $\mathrm{F}$ & total & M & $\mathrm{F}$ & total & M & $\mathrm{F}$ & total \\
\hline very diverse & 8.76 & 17.65 & 9.74 & 18.98 & 5.88 & 17.53 & 24.09 & 17.65 & 23.38 \\
\hline up to $100 \mathrm{~km}$ & 6.57 & 5.88 & 6.49 & 7.30 & 17.65 & 8.44 & 11.68 & 17.65 & 12.34 \\
\hline over 200 km & 2.92 & 0.00 & 2.60 & 5.84 & 11.76 & 6.49 & 7.30 & 5.88 & 7.14 \\
\hline in the vicinity & 4.38 & 0.00 & 3.90 & 0.73 & 0.00 & 0.65 & 1.46 & 0.00 & 1.30 \\
\hline total & 22.63 & 23.53 & 22.73 & 32.85 & 35.29 & 33.11 & 44.53 & 41.18 & 44.16 \\
\hline
\end{tabular}

Source: based on questionnaires

Only $30 \%$ of respondents said that they travel alone. Trips with friends prevailed (54\%) while those with family were $12 \%$ and $4 \%$ with a partner.

An analysis of the mileage travelled by motorcyclists was made. Unfortunately, it was impossible to determine how many kilometres the respondents travelled for motorcycle tourism alone. However, if it is assumed, according to the answers, that on average, about $30.4 \%$ of the time motorcycles were used was spent on tourism, and another $29.7 \%$ on entertainment and $21.2 \%$ on daily commuting, then approximately one-third of the annual mileage took place during motorcycle trips.

The average annual mileage is almost 10000 kilometres with a median value of 8000 kilometres. Most respondents indicated a range from 2000 to 6000 kilometres. It can be assumed that mileage of over $20000 \mathrm{~km}$ in the high season is very rare. An example is a five-day trip from Kraków to Kashubia, during which the participants travelled $1955 \mathrm{~km}$. Analysing the preferred nature of PTW vehicle use on a scale from zero (no such activity) to five, the respondents rated tourism (average weight 4.25) and entertainment (4.16) the highest. Daily transport was only 2.97, while hobbies and sports were below 1.5. Therefore, it can be concluded that the dominant uses are for motorcycle tourism and entertainment, and there are doubts on how to distinguish between these two types of activity. The survey noted that tourism is mainly for sightseeing, but recreational trips partially meet the criteria for motorcycle tourism, as described in the introductory section.

When calculating the average mileage of vehicles for individual uses, a weighted average was used, where the weight was to determine the preferences for using PTW vehicles by the respondents. Among the three most important types, those who mentioned tourism $(9700 \mathrm{~km})$ achieved the highest annual mileage. According to the average distance travelled, the next is entertainment $(9400 \mathrm{~km})$ and daily commuting $(9100$ $\mathrm{km})$. High values $(10900 \mathrm{~km})$ were shown by those pointing to sport as the primary purpose. This may be because riders who are enthusiasts, e.g. cross, enduro or trial, more often use their vehicles for training (even three times a week, and in addition, the motorcycle season often does not end in autumn but continues in winter). Interviews with riders involved in motorcycle sports confirm this. However, due to its low importance, this result was not considered in further analyses. 
Figure 2. Average preferences when choosing a motorcycle trip route according to respondents

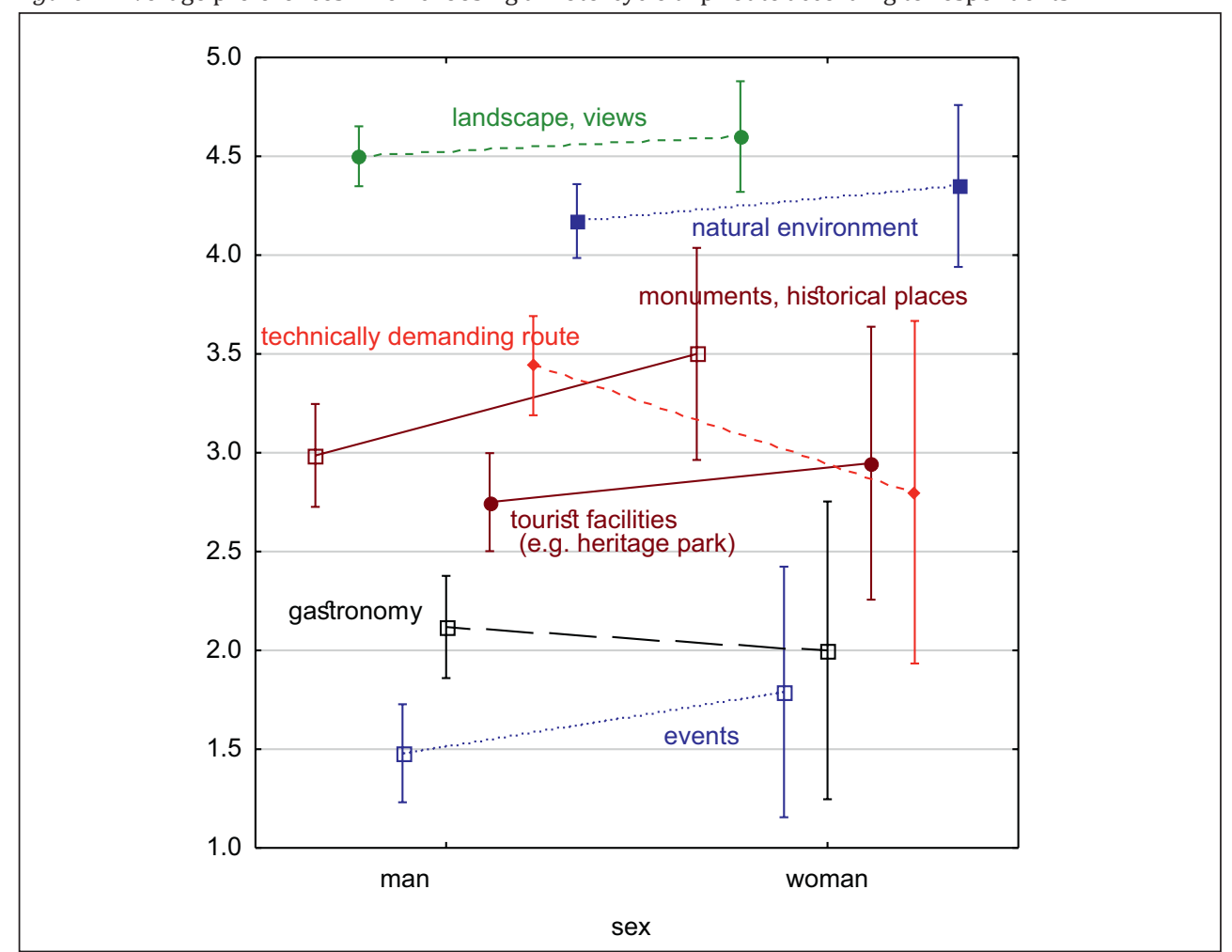

Source: author based on questionnaires

Assuming, therefore, that motorcycle tourism accounts for approximately $30 \%$ of activity, it can be concluded that Polish motorcycle tourists cover an average of 2900 kilometres. Based on data on the tourist destinations of motorcyclists, this is the distance, for example, from Poland to Croatia (and back + stay) - approximately $2000 \mathrm{~km}$, and less than $1000 \mathrm{~km}$ for weekend trips up to approximately $200 \mathrm{~km}$ from the place of residence.

The type of vehicle used also affects the annual mileage. The greatest was recorded by owners of tourist motorbikes (median $10000 \mathrm{~km}$ ), while a high figure was also indicated by users of large motorcycles such as choppers and cruisers but they refer to a small number of respondents and usually longer journeys. The lowest average was found for scooters (median $3800 \mathrm{~km}$ ), mainly related to their intended use for everyday communication over short distances. In more than half of the cases, the average annual mileage does not exceed $10000 \mathrm{~km}$ (except for the aforementioned large motorcycles).

Another interesting aspect of motorcycle tourism is preferences when choosing a tour route, so respondents were asked what they were guided by. Due to the noticeable differences, the analyses were broken down by gender (Figure 2). On a scale of 1 to 5 , the highest value was given to the landscape and views that can be seen during the trip. These aesthetic experiences are challenging to classify, but it can be assumed that they will undoubtedly be mountain regions, lakes and coastal areas. Therefore, this category includes so-called viewpoints and entire routes, e.g. along a river valley 
or on the peaks of a mountain range (mountain passes). The natural environment is in second place, partly related to landscape (an essential part of it), especially forest areas (including nature reserves and national and landscape parks). In both, these factors were indicated by men and women alike, although in the case of women, the average weight was slightly higher than for men, with a more significant variation in responses. This was particularly evident in assessing the importance of the natural environment, which was of the most significant importance for several women when choosing the route. Therefore, it can be concluded that women are more sensitive to the beauty of nature and landscape than men.

For other factors, there is a clear difference between women and men. For men, a technically demanding route was in third place with an average value of about 3.5. This factor is associated with emotions and "adrenaline" when taking sharp turns or reaching high speeds. On the other hand, for women, monuments and historical places were in third place with an average of about 3.5, which for men weighted 3.0. Tourist facilities (such as museums, including open-air) were rated more highly by women than men. For men, the attractiveness of these places was the same as demanding routes were for women, receiving an average rating of approximately 2.8 .

The lowest rated factors influencing route choice were gastronomy (approximately 2), which was rated more highly by men than women. Events, such as motorcycle rallies, concerts, air shows, etc., were ranked lowest: by women at around 1.7 and by men at 1.5 .

Even though events as a determinant of route selection were rated lowest, the motorcyclists surveyed take part in motorcycle events on average 2.5 times a year, with the most popular events at the start and end of the motorcycle season (47\%). Next in line are motorcycle rallies organised by various clubs and associations throughout Poland and abroad. Religious events are also popular, e.g. the star rally in Częstochowa (about 50000 motorcyclists in 2018), motorcycle pilgrimages (e.g. Licheń, Lubomierz, Rokitno, Wambierzyce), masses for motorcyclists (e.g. Stara Iwiczna, Stary Sącz) or meetings in Lednica (Lednica 2000). Rallies and meetings are associated with other events, such as the cyclical Woodstock festival (Wielka Orkiestra Świątecznej Pomocy).

It should be noted that organised events for motorcyclists very often have a sightseeing element in their program. Event venues are often located in tourist destinations (e.g. Karpacz, Łeba, Mikołajki) and with attractions such as monuments (e.g. castles) or natural sites (e.g. lakes). A vital place for motorcycle rallies are those associated with historical events (e.g. Battle of Grunwald).

To verify the preferences that influence route choice, the participants were asked to indicate places worth visiting by motorcyclists in their region. Monuments were ranked first (38\% of responses), including tourist facilities such as open-air museums (e.g. Kielce Skansen). Interesting scenic routes were ranked second, mainly in the mountains (passes) or other highlands and along river valleys (e.g. the Poprad valley). Slightly less, because $19 \%$ of responses recommended places related to nature were national parks (e.g. Pieniny National Park), nature reserves (e.g. Bór na Czerwonem) or natural monuments (e.g. Bartek oak). Other attractions are the mountains (e.g. the Bieszczady, Świętokrzyskie, Tatra Mountains), lakes (e.g. Czorsztyńskie). The smallest number indicated attractions related to gastronomy (cream cake in Wadowice or ice cream in Nowy Targ) and regional events (e.g. Watra Łemkowska in Zdynia). Therefore, 
it should be stated that monuments and natural conditions (landscape) constitute the most significant potential for motorcycle tourism. Moreover, $72 \%$ of the respondents indicated that they use gastronomy during their trips.

The survey also took into account the sources of information that motorcyclists follow when planning their trips. Most information and ideas for expeditions are taken from internet portals (35\% of responses), while maps and tourist guides were used in about $28 \%$ of cases. Friends and acquaintances were also an important source, as approximately $24 \%$ of respondents followed their advice. Riders motivated by the location of events constitute another $10 \%$, while those remaining indicated media such as radio and television. There are significant age differences among these choices: the youngest indicated websites and the internet mainly, while the older indicated maps and guides and the locations of events.

Regardless of age, over $80 \%$ of respondents use GPS satellite navigation while travelling. Planning a route using electronic devices and access to the database of tourist facilities included in many applications can significantly contribute to the attractiveness of given regions. Additionally, many internet portals offer GPS traces of trips with their description and characteristics. Therefore, the distance and time for a planned trip in a given region can be found, and the program will search for routes that meet the given criteria.

At the same time, motorcyclists use other technical solutions that facilitate group journeys. An example is an intercom that allows several people to talk while riding and was used by about $72 \%$ of the respondents.

\section{CONLUSIONS}

Motorcycle tourism is a segment that has seen a substantial increase in interest in Poland and globally. The factors that encourage PTW vehicle drivers to set off on a journey are mainly consistent with the goals of other tourists and differ only in the way they travel.

In Poland, motorcycle tourists are mainly male, but with a noticeable increase in popularity among women. They are usually middle-aged and, on average, make one longer (foreign) and several weekend trips a year. The destinations are popular tourist regions, mainly mountainous areas, which provide both views and technically demanding routes.

In summary, a statement posted on a social forum can be presented: What makes us decide to spend time and energy on trips? It is difficult to answer this unequivocally from the perspective of anyone who gets on a motorcycle and rides. (...) We can travel around our land to see something with our own eyes. We go to Croatia on holiday. We send the motorcycle and fly to it by plane near the steppes of Mongolia. We ride around Africa. (...) Travelling with a laden motorcycle is certainly a driving force to get to know oneself, relationships between people, and cultural differences. It is an inspiration to colour life, gather impressions, develop, collect memories and adventures that go beyond everyday life. It can even be a way of life. (https://pl-pl.facebook.com/CFact1/ posts/3215876981768984). 


\section{References}

Arnould, E.J., Price, L.L. (1993). River magic. Extraordinary experience and the extended services encounter. Journal of Consumer Research, 20(1), 24-45.

Austin, D.M., Gagne, P. (2008). Community in a mobile subculture. The world of the touring motorcyclist. Studies in Symbolic Interaction, 30, 411-437.

Biedroń, A. (2011). Turystyka motocyklowa w Polsce. Charakterystyka zjawiska i konsumentów. Prognoza rozwoju. Warszawa: Difin.

Botterill, D., Owen, R., Emanuel, L., Foster, N., Gale, T., Nelson, C., Selby, M. (2000). Perceptions from the periphery. The experience of Wales. In: F. Brown, D. Hall (eds.), Tourism in peripheral areas. Case studies. Clevedon: Channel View Publications, 7-38.

Carson D., Cartan G. (2011). Touringroutes - types, successes and failures. an international review. In: B. Prideaux, D. Carson (eds.), Drive Tourism. Trends and Emerging Markets. Oxon: Routledge, 296-310.

Carson, D., Taylor, A. (2008). Sustaining four wheel drive tourism in desert Australia. Exploring the evidence from a demand perspective. The Rangeland Journal, 30(1), 77-83.

Cater, C. (2017a). Longway up. Peripheral motorcycle tourism to the North Cape. In: D. Weaver, Y.S. Lee, N. Prebensen (eds.), Arctic Tourism Experiences. Production, Consumption, and Sustainability. CABI Publishing. Retrieved from https://core.ac.uk/download/ pdf/185312147.pdf.

Cater, C. (2017b). Tourism on two-wheels. Patterns of Motorcycle Leisure in Wales. Tourism Management, 61, 180-189. doi: https://doi.org/10.1016/j.tourman.2017.02.007.

Chorlton, K., Jamson, S.L. (2003). Who rides on our roads? An exploratory study of the UK motorcycling fleet. In: Behavioural Research in Road Safety. Thirteenth Seminar Proceedings. London: DfT.

Corey, R. (1997). A drama-based model of traveller destination choice. Journal of Travel \& Tourism Marketing, 5(4), 1-22.

Dorocki, S. (2019a). Użytkowanie motocykli i motorowerów w Polsce na początku XXI wieku. Prace Komisji Geografii Komunikacji PTG, 22(4), 34-45.

Dorocki, S. (2019b). Przestrzenne zróżnicowanie rozwoju rynku silnikowych pojazdów dwu-lub trzykołowych (PTW) w Polsce na początku XXI w. Prace Komisji Geografii Komunikacji PTG, 22(2), 8-19.

Dorocki, S., Wantuch-Matla, D. (2021). Power Two-Wheelers as an Element of Sustainable Urban Mobility in Europe. Land. MDPI, Open Access Journal 10(6), 618. doi: https://doi. org/10.3390/land10060618.

Hall, L. (2013). 'My wanderlust is not yet appeased'. Ellis Bankin and motorcycle touring in 1930s Australia. Studies in Travel Writing, 17(4), 368-383.

Hermawati, P., Adisasmita, S.A., Ramli, M.I., Hamid, S. (2019). Choices Models of Trip Chain and Transportation Mode for International Tourists in Tourism Destination Island. International Journal, 16(55), 195-203.

Hohl, A.E., Tisdell, C.A. (1995). Peripheraltourism. Development and management. Annals of Tourism Research, 22(3), 517-534.

Jansen-Verbeke, M. (2008), Ageographer's gaze at tourism. Documentsd'Ana 'lisi Geogra 'fica, 15 (2), $15-29$.

Kosmaczewska, J. (2013). Turystyka jako czynnik rozwoju obszarów wiejskich. Poznań: Bogucki Wydawnictwo Naukowe.

Kurek, A. (2008). Na tropach galicyjskiej turystyki motorowej. Folia Turistica, 19, 91-112.

Lamont, M. (2009). Reinventing the wheel. A definitional discussion of bicycle tourism. Journal of Sport \&Tourism, 14(1), 5-23.

Łysoń, P. (ed.). (2019). Turystyka w 2018 r. Warszawa: Główny Urząd Statystyczny.

McInnes, R.J., Williamson, L.M., Morrison, A. (2002). Unintentional injury during foreign travel. Journal of Travel Medicine, 9, 297-307.

Panek, T. (2015). Jakość życia gospodarstw domowych w Polsce w układzie wojewódzkim. Zeszyty Naukowe Instytutu Statystyki i Demografii SGH, 46, 2-111.

Pinch, P., Reimer, S. (2012). Moto-mobilities. Geographies of the motorcycle and motorcyclists. Mobilities, 7(3), 439-457. 
Price-Davies, E. (2011). Adventure motorcycling. The tourist gaze. International Journal of Motorcycle Studies, 7(1), 1-7.

Ritchie, J.R.B., Hudson, S. (2009). Understanding and meeting the challenges of consumer/tourist experience research. International Journal of Tourism Research, 11, 111-126.

Schouten, J., McAlexandar, J. (1995), Subcultures of consumption: an ethnography of the new bikers. Journal of Consumer Research, 22(3), 43-61.

Shih, H.Y. (2006). Network characteristics of drive tourism destinations. An application of network analysis in tourism. Tourism Management, 27(5), 1029-1039.

Sosnowski, F. (2015). Turystyka motorowa w Polsce w dekadzie Edwarda Gierka. In: T. DrozdekMałolepsza, A. Buková (eds.), Teoretyczne i praktyczne uwarunkowania kultury fizycznej i turystyki. Częstochowa: Wydawnictwo im. Stanisława Podobińskiego Akademii im. Jana Długosza w Częstochowie, 47-61.

Spring, U. (2017). Early Mass Tourism at the North Cape. Infrastructure, Environment and Social Practices. In: H. Hansson, A. Ryall (eds.), Modernities. The Environmental, the Exotic and the Everyday. Newcastle upon Tyne: Cambridge Scholars Publishing, 130-157.

Swanson, R.A. (2007), Theory framework for applied disciplines. Boundaries, contributing, core, useful, novel, and irrelevant components. Human Resource Development Review, 6(3), 321339.

Sykes, D.M., Kelly, K.G. (2014). Motorcycle tourism demand generators and dynamic interaction leisure. International Journal of Culture, Tourism and Hospitality Research, 8(1), 92-102.

Sykes, D., Kelly K.G. (2016). Motorcycle drive tourism leading to rural tourism opportunities. Tourism Economics, 22(3), 543-557. doi: https://doi.org/10.5367/te.2014.0454.

Urry, J. (2002), The Tourist Gaze. London: Sage Publications.

Walker, L. (2011). Tourism and leisure motorcycle riding. In: B. Prideaux, D. Carson (eds.), Drive Tourism. Trends and Emerging Markets. New York: Routledge, 146-158.

Way, K.A., Roberts, L.J., Turner, J. (2010). Travel and spending characteristics of the mature biker. An exploratory study. Caesars Hospitality Research Summit, 12. Retrieved from https://digitalscholarship.unlv.edu/hhrc/2010/june2010/12 (dostęp 12.06.2021).

Weidenfeld, A., Butler, R. Williams, A. (2010). Clustering and compatibility between tourism attractions. International Journal of Tourism Research, 12(1), 1-16.

Wilk, K., Tarnowski, M., Chołaściński, A., Terczyński, R., Eider, P. (2017). Geografia wybranych doświadczeń krajoznawczych motocyklistów uprawiających turystykę skuterową zrzeszonych w klubie Burgmania. Handel Wewnętrzny, 4/2, 290-303.

Zalega, T. (2013). Nowe trendy i makrotrendy w zachowaniach konsumenckich gospodarstw domowych w XXI w. Konsumpcja i Rozwój, 2, 3-21.

Zawadka, J. (2015). Podróże motocyklowe jako niszowa forma turystyki kwalifikowanej oraz preferencje i zachowania ich uczestników. Prace Naukowe Uniwersytetu Ekonomicznego we Wrocławiu, 379, 156-164.

Sławomir Dorocki, PhD, Pedagogical University of Krakow, Institute of Geography, Department of Entrepreneurship and Spatial Management. He graduated from the Pedagogical University of Krakow with an MA degree in Geography and obtained a PhD in History (Institute of European Studies of the Jagiellonian University). He is an associate professor at the Pedagogical University of Krakow, Institute of Geography. His research interests are connected to regional problems and processes of socio-economic regionalisation, with particular emphasis on the diversity of Europe, processes of European integration, historical conditions and application of computer and statistical methods in the study of the diversity of space.

\section{ORCID: https://orcid.org/0000-0001-6083-0346}

\section{Address:}

Pedagogical University of Krakow

Institute of Geography

ul. Podchorążych 2

30-084 Kraków, Poland

e-mail: slawomir.dorocki@up.krakow.pl 